\title{
Michel Crouzet, Stendhal en tout genre. Essais sur la poétique du Moi
}

\section{Michel Arrous}

\section{Q OpenEdition \\ 1 Journals}

\section{Édition électronique}

URL : https://journals.openedition.org/studifrancesi/46044

DOI : 10.4000/studifrancesi.46044

ISSN : 2427-5856

Éditeur

Rosenberg \& Sellier

\section{Édition imprimée}

Date de publication : 1 octobre 2007

Pagination : 461-462

ISSN : 0039-2944

\section{Référence électronique}

Michel Arrous, « Michel Crouzet, Stendhal en tout genre. Essais sur la poétique du Moi », Studi Francesi [En ligne], 152 (LI | II) | 2007, mis en ligne le 30 novembre 2015, consulté le 24 novembre 2021. URL : http://journals.openedition.org/studifrancesi/46044; DOI : https://doi.org/10.4000/studifrancesi. 46044

Ce document a été généré automatiquement le 24 novembre 2021.

\section{(c) 9 (i) $\Theta$}

Studi Francesi è distribuita con Licenza Creative Commons Attribuzione - Non commerciale - Non opere derivate 4.0 Internazionale. 


\title{
Michel Crouzet, Stendhal en tout genre. Essais sur la poétique du Moi
}

\author{
Michel Arrous
}

\section{RÉFÉRENCE}

MICHEL CROUZET, Stendhal en tout genre. Essais sur la poétique du Moi, Paris, Honoré Champion, 2004, pp. 341.

Ce recueil de neuf études publiées, séparément entre 1976 et 1991, vient compléter Stendhal. La Politique. L'Eros. L'Esthétique (Eurédit, 2003), précédent volume de douze études publiées entre 1967 et 1992, soit à une époque où régnait la rationalité structuraliste. C'est donc d'abord le témoignage d'un esprit libre dans lequel on retrouve les axes principaux de la pensée de Michel Crouzet et, particulièrement, la preoccupation générique, mais délivrée des strictes contraintes canoniques. Sont privilégiés quelques genres proprement stendhaliens: le journal intime, l'autobiographie, le récit de voyage et le pamphlet, c'est-à-dire une écriture du fragment à la première personne et au présent. Dans sa stimulante préface, crouzet rappelle qu'à travers ces genres, dans un mouvement sans fin, se décline le moi beyliste, le moi écrivain et surtout le moi écrivant, «créateur d'une poétique qui le crée». Avec Stendhal, et à la différence de Maine de Biran, de Constant ou d'Amiel, l'expérience du journal n'est plus vécue sur le seul mode narcissique du «tête-à-tête spéculaire», mais comme un effort pour «être bien soi» et donc «être bien avec soi». Chez lui, le dédoublement intimiste obéit à une éthique du naturel, que Valéry suspecta de parti pris, et de la liberté. Cette expérience se retrouve dans l'autobiographie manifeste ironique contre l'antinaturel, contre Chateaubriand «parlant trop de lui»-, dans le récit de voyage - un voyageur tout au plaisir de voyager, débarrassé des conventions du genre, écrit un livre qui n'en est pas un -, et dans le pamphlet - dans sa lutte contre le délire académique ou industrialiste, railleur mais honnête homme, Stendhal abandonne la maligniti au profit de la politesse, ou plutôt de la violence polie. Autant d'approches des moi de Stendhal qui se garde aussi bien de l'autosatisfaction 
que de l'auto-dénigrement. Bien que publiées sans pian préconçu, ces études forment un ensemble dont la cohérence est évidente. 